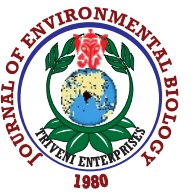

\title{
Recent trends and impacts of climate change in North-Eastern region of India-A review
}

\author{
A. Roy ${ }^{1 *}$, D. Kolady', B. Paudel', A. Yumnam 1 , N. Mridha ${ }^{3}$, D. Chakraborty and N.U. Singh ${ }^{1}$ \\ 'Division of Social Sciences, ICAR Research Complex for NEH Region, Umiam-793 103, India \\ ${ }^{2}$ Ness School of Management and Economics, South Dakota State University, Brookings-57006, SD, USA \\ ${ }^{3}$ Quality Evaluation and Improvement Division, ICAR-NINFET, Regent Park, Kolkata-700 040, India \\ ${ }^{4}$ Division of Agril. Engineering, ICAR Research Complex for NEH Region, Umiam-793 103, India \\ *Corresponding Author Email : aniruddha.roy@icar.gov.in
}

\begin{abstract}
The economy of North-Eastern (NE) region of India predominantly depends on farming, where only $12 \%$ of geographical area is available for cultivation out of which more than $85 \%$ is rain fed. Climate change has become a major concern in agriculture today, as farmers in many regions are struggling to cope with changing temperatures and rainfall pattern. Moreover, extreme weather situations like droughts, floods, heat and cold waves pose serious threat to food security, especially for small and marginal farmers. This review paper discusses the climate change in North-Eastern India based on the available climatic data from various published sources.
\end{abstract}

Most of the analysis was performed on time series meteorological data recorded at different locations across the states of North-Eastern India namely, Assam, Arunachal Pradesh, Sikkim, Nagaland, Meghalaya, Manipur, Mizoram and Tripura.

The increase in mean annual maximum temperature varied from $0.1^{\circ} \mathrm{C}$ per decade in Imphal (Manipur) to about $1.4^{\circ} \mathrm{C}$ per decade in Jharnapani (Nagaland). The changes were significant for all the states, except Sikkim. This region is one of the highest rainfall receiving regions of the world, but during February-March it faces water scarcity. The rainfall is projected to increase in 57 districts out of 78 districts, with some districts expected to experience almost $25 \%$ more rainfall than usual.

The North-Eastern region of India has experienced notable changes in the pattern of major climatic variables such as rainfall and temperature. Average temperatures are projected to increase in almost all the districts of the region while annual rainfall is also reported to increase in almost $3 / 4^{\text {th }}$ of the districts. The climate-induced natural disasters like drought, flood and hailstorms are the major threats of climate change and the incidence of these natural disasters are increasing in the recentyears over the region.

Key words: Agriculture, Climate Change, Impact, North-Eastern India, Trend

How to cite : Roy, A., D. Kolady, B. Paudel, A. Yumnam, N. Mridha, D. Chakraborty and N.U. Singh: Recent trends and impacts of climate change in North-Eastern region of India-Areview. J. Environ. Biol., 42, 1415-1424 (2021). 


\section{Introduction}

Weather and climate have significant influence on life on the earth. They are part of daily experience and are essential for health, food production and wellbeing. The climate of earth is always changing through a natural cycle. But in the last 150 years, the climate change witnessed has been rapid, definite trend towards warming. Most of the climate change observed over the last 50 years is attributed to human activities (IPCC. Synthesis Report 2001). In a poll conducted by TIME magazine, 31\% respondents said that climate change is due to human activities, $19 \%$ of them reported that it is due to natural causes while $49 \%$ of them had opined that climate change is due to both natural and human causes. Now a days climate change has become a major concern for Indian agriculture, with farmers in many regions are struggling to cope with changing temperatures and rainfall patterns. Moreover extreme weather situations like droughts, floods, heat and cold waves poses serious threat to food security, especially for small and marginal farmers.

The Inter-Government Panel on Climate Change (IPCC, 2007) has projected a possible increase in temperature between $1.5^{\circ} \mathrm{C}$ and $5.8^{\circ} \mathrm{C}$ with the best possible value of $3.8^{\circ} \mathrm{C}$ by 2100 $A D$. The net result of climate change as anticipated could be recurring drought and floods and significant changes in production environments. As a result, the estimated crop loss will be around of $10-40 \%$ in India with increase in temperature by 2080-2100. (IPCC, 2007). The phenomenon of climate change is associated with long-term change in global weather indicators, like increase in temperature, precipitation, mean sea level, the retreating of glaciers and storm activity. The direct consequence of continued anthropogenic emissions from fossil fuel burning is increase in the atmospheric $\mathrm{CO}_{2}$ leading to climate change (Cox et al., 2000). In recent years, climate change with diverse forms of footprints in various spatio-temporal dimensions and scales becomes a challenging reality which is posing a serious threat to food security (Scholz and Hasse, 2008). As global warming and other weather perturbations are throwing a dire warning, scientists and policy makers have been searching for ways to tackle the alarming risk of climate change (Herzog, 2001).

In India, one of the most vulnerable regions is the Northeastern part which is largely composed of subtropical humid climate and encompasses the small states of Assam, Arunachal Pradesh, Tripura, Nagaland, Manipur, Mizoram, Meghalaya and Sikkim covering a geographical area of 26.2 million ha and a population of 50.92 million (RCM Document, Zone III, ICAR, 2019). Forest cover in the North-eastern region of India is 14.2 million ha, which is about $54.16 \%$ of total geographical area of this region (ICAR RC for NEHR Vision Document, 2020). By and large, the region is characterized by fragility, marginality, inaccessibility, cultural heterogeneity, diverse ethnicity and rich biodiversity. Rural population (82\%) is agrarian and depends on agriculture and allied sectors for livelihood in the absence of industries, except in the state of Assam. Around $56 \%$ of the area of the region is under low altitude, $33 \%$ in mid-altitude and $11 \%$ under high altitude. The agricultural production system is characterized by CDR (Complex Diverse Risk-prone) type, with low cropping intensity, subsistence farming, undulating topography and faulty land use pattern with annual soil- loss of about 46 tha $^{-1}$ (Roy et al., 2015). Jhum (shifting) cultivation is one of the prevailing agricultural practices in North-eastern region since ages and is considered to cause severe land degradation. Farming system in this region is predominated by subsistence farming, where shifting cultivation still remains important. In the absence of any scientific consensus on Jhum cultivation plans, given the possibility of significantly adverse impacts of moderate as well as catastrophic climate change on North-Eastern region of the country, both adaptation and mitigation policy options are required for careful attention to address the issue over the region.

Trends in climatic variables: The global temperature has been increasing day by day and the global average temperature has increased by $0.85^{\circ} \mathrm{C}$ during $1880-2012$ while the last 30 years remains as the warmest in the last 1400 years history of the earth (IPCC 2013; Chakraborty et al., 2018; IPCC, 2007a). During 2018, 11 of 12 monthly global land and ocean temperature departures from average ranked among the five warmest for their respective months, giving way to fourth warmest year in NOAA's 139-year record (Global Climate Report- 2019, National Centers for Environmental Information). According to data from NASA, the global average temperature in 2013 was $58.3^{\circ} \mathrm{F}\left(14.6^{\circ} \mathrm{C}\right)$, roughly a degree warmer than the average of $20^{\text {th }}$ century (NASA New Release 14-024). In India, the annual mean temperature has risen by $0.56^{\circ} \mathrm{C}$ over the period from $1901-2009$ and the annual mean temperature has been generally above normal (normal based on period, 1961-1990), since 1990 (IMD, 2009).Various studies present trend analysis of climatic variables over the North-eastern region in discrete manner.

From these studies we can get a glimpse of the overall trend of climatic changes over the region. Trend indicates a gradual change occurring over a certain time period (Shahin et al., 1993). The seasonal analysis over the last 30 years indicate that, decadal increase in mean winter temperature was at the rate of $0.8^{\circ} \mathrm{C}$ over NE region (Chakraborty et al., 2017a). There was a significant increase in minimum, mean and maximum temperature of $\sim 0.64^{\circ} \mathrm{C}, 1.09^{\circ} \mathrm{C}$ and $1.5^{\circ} \mathrm{C}$, respectively, per 100 years during post-monsoon months and $\sim 0.61^{\circ} \mathrm{C}, 0.92^{\circ} \mathrm{C}$ and $1.2^{\circ} \mathrm{C}$ per 100 years during winter season (Deka et al., 2009). Similarly, a decadal increase in the annual mean and maximum temperature was reported at a rate of $0.04^{\circ} \mathrm{C}$ and $0.11^{\circ} \mathrm{C}$ over this region (Pant and Rupa Kumar 1997; Das 2004). The meteorological data analysis further indicates that in Basar (Arunachal Pradesh), the decadal increase in average temperature (Tavg) ranged between $0.5^{\circ} \mathrm{C}$ to $1.6^{\circ} \mathrm{C}$; while in Gangtok (Sikkim) and Imphal (Manipur), these were $0.2^{\circ} \mathrm{C}$ to $0.6^{\circ} \mathrm{C}$ and $0.2^{\circ} \mathrm{C}$ to $0.3^{\circ} \mathrm{C}$ respectively (Chakraborty et al., 2017a). An interesting observation was that the mean and maximum annual temperature has increased significantly over most of the parts of the region during last three decades but minimum annual temperature showed diverse trend, at some 


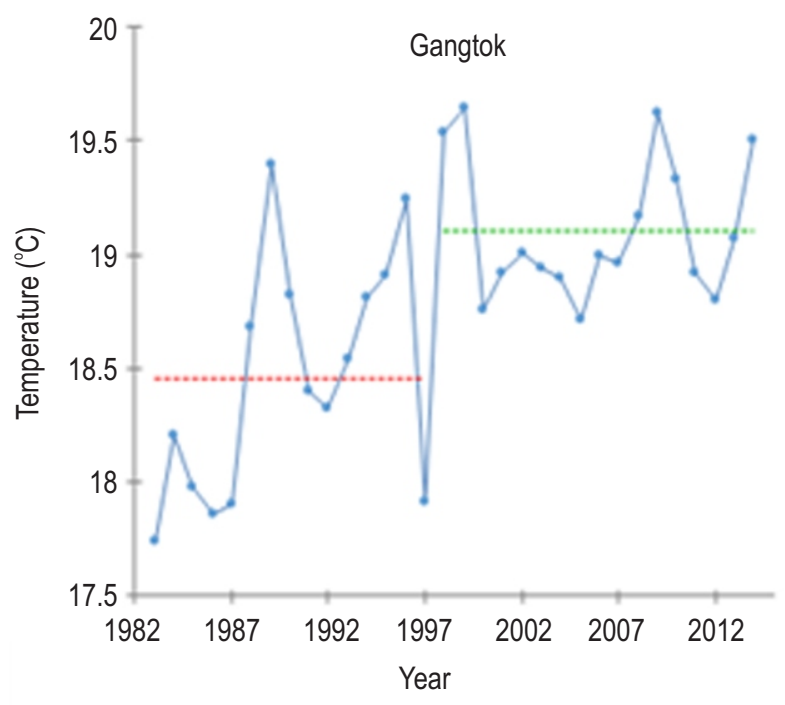

$\ldots$ Annual $\ldots \ldots \ldots$ mu1=18.451 $\ldots \ldots \ldots$ mu2=19.107



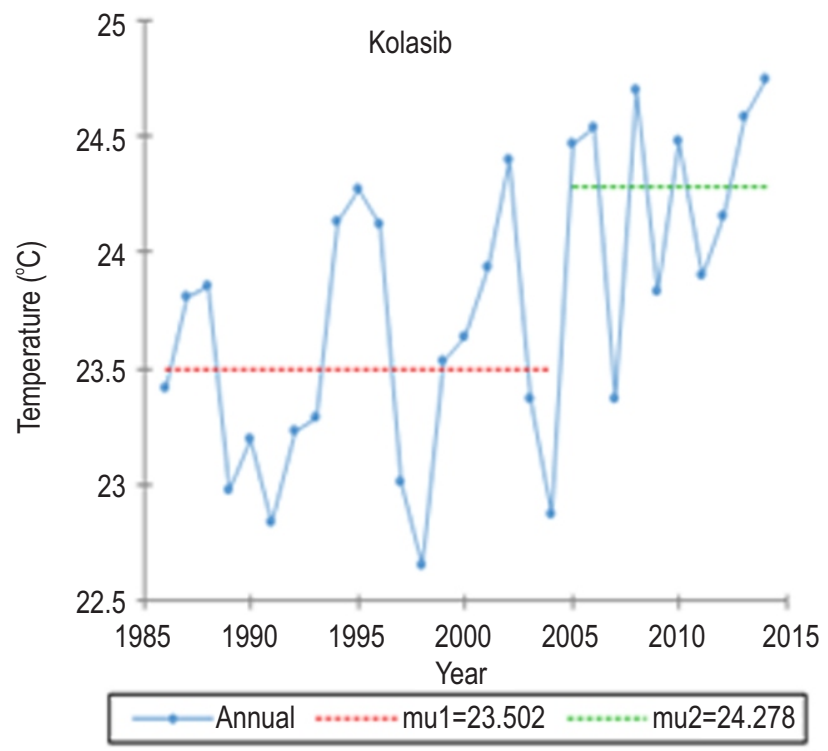

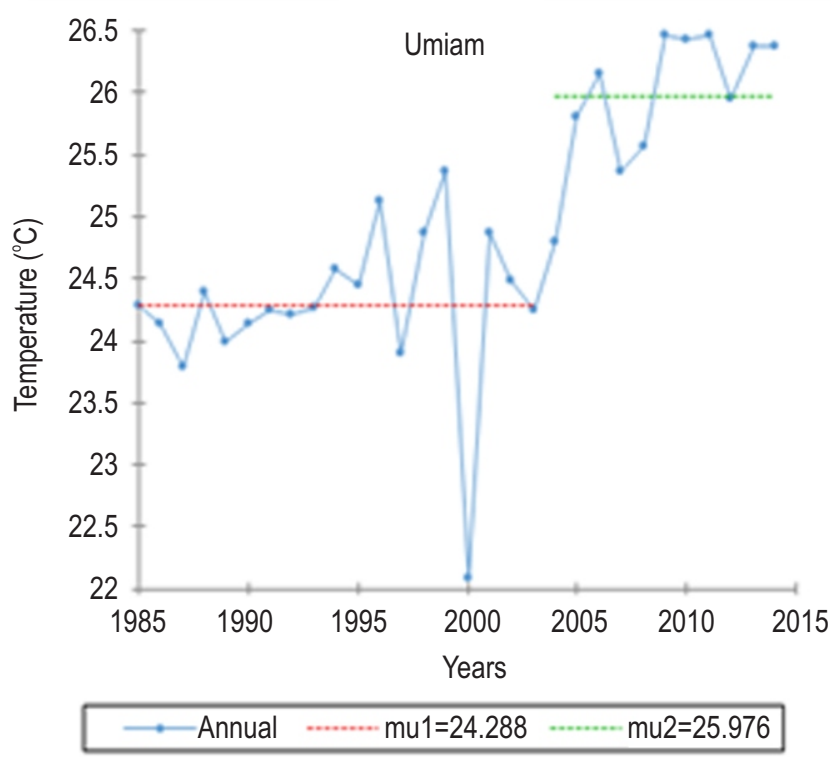

Fig. 1: Time series of mean annual temperature $\left(\mathrm{T}_{\text {avg }}\right)$ at different places of North-east India indicating the change points (source: Chakraborty et al., 2017a).

places it increased and some places it decreased (Chakraborty et al., 2014, 2017a; Deka et al., 2009). Over some places, reverse trend in the maximum $\left(T_{\max }\right)$ and minimum $\left(T_{\min }\right)$ temperatures increased the diurnal temperature range $\left(\right.$ DTR $\left.=T_{\max }-T_{\min }\right)$ (Jhajharia and Singh, 2011). Analysis of temperature data in NE region by S.K. Jain et al. (2013) showed that all four temperature variables (maximum, minimum, and mean temperatures and temperature range) showed rising trend. Notably for postmonsoon season, the Sen's estimators of slope $\left({ }^{\circ} \mathrm{C} /\right.$ year) was $0.019,0.011$ and 0.015 for the maximum, minimum, and mean temperature, respectively. Apart from the trend analysis, it is also very pertinent to know the time from when these changes have started to occur. For that change point analysis was carried out and the results indicate that most changes over the region started during 1990s to early 2000s as depicted in Fig. 1 (Chakraborty et al., 2017a). Over the North-east region there is high spatial variability in rainfall anomaly and most importantly there is existence of the difference in the pattern of trends of $\mathrm{NE}$ regional rainfall vis-à-vis national level (Saha et al., 2018).

The annual rainfall in Kamrup District of Assam for 117 years (1901-2017) showed no significant trend till 2000 but after 


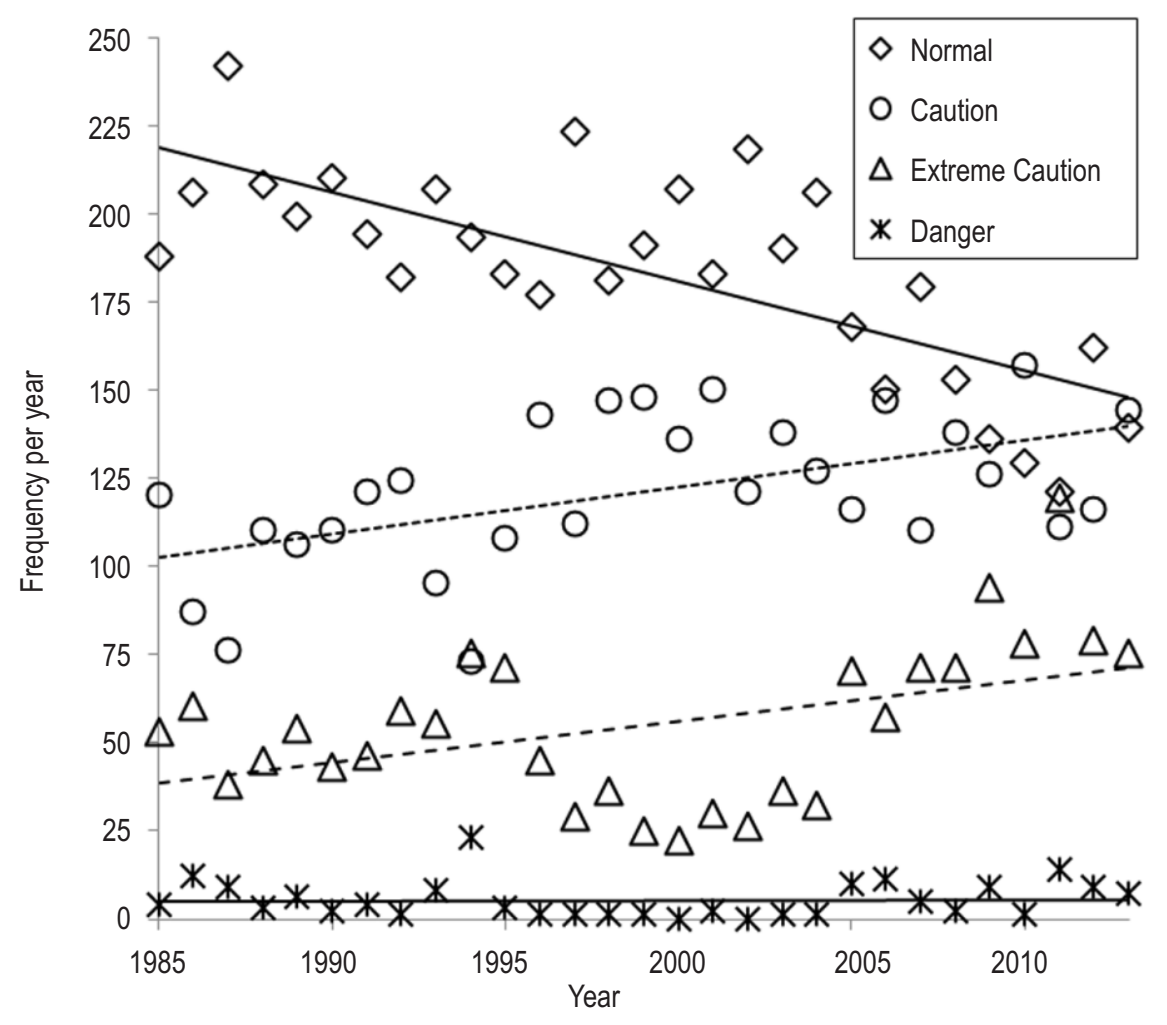

Fig. 2: Change in different categories of Heat Index (Source: Chakraborty et al., 2014).

that it showed a declining trend (Barman and Goswami, 2019). The annual standardized precipitation index (SPI) trend map confirmed an increasing trend in dry conditions over southern Mizoram which may pose a severe warning to rabi vegetable cultivation in order to enhance the cropping intensity (Saha et al., 2015; Saha et al., 2016). The decrease in winter rainfall was also reported over several parts of the region (Chakraborty et al., 2017b). The study on gridded rainfall dataset for the period 1951-2004 showed that the annual average rainfall remained unchanged, but the frequency of heavy rainy days increased significantly during the monsoon months in NE making the region more flood prone (Dash et al., 2009). Jain et al. (2013) analyzed rainfall and temperature trends in North-east India.

Trends in monthly, seasonal, and annual rainfall and temperature on the subdivision and regional scale for the NER were examined in this study. Trend analysis of rainfall data series for 1871-2008 did not show any clear trend for the region as a whole, although there were seasonal trends for some seasons and for some hydro-meteorological subdivisions. Seasonal rainfall patterns over the region also depicted changes but many a times they were not statistically significant, but it was very clear that winter rainfall has been decreasing over the region (Table 1). During pre-monsoon and monsoon seasons, pan evaporation (Epan) was found to be decreasing over NE India (Jhajharia et al., 2009). Jhajharia et al. (2009) observed an increasing trend in relative humidity $(\mathrm{RH})$ during winter and pre-monsoon seasons over North-east India leading to warming over the surface by trapping more heat due to more water vapor in the atmosphere. The trends of relative humidity (morning and evening) were also in the reverse direction, the former by increased and the later decreased due to the fact that atmosphere at higher temperature can retain higher amount of moisture and vice-versa (Chaudhury et al., 2012).

Occurrence of extreme events: Extreme weather events act as an indicator for the existence of climate change (Katz and Brown, 1992) and presently the global climate is experiencing more extremes than ever before which are predicted to increase further in the near future (Chakraborty et al., 2019). The primary impact of climate change on the society is through the extreme events (Parry and Carter, 1985) such as floods, droughts, cyclones, hail storm and thunderstorm. Flash floods associated with extreme rain events are major hydrological disaster in the region because of the unique topographic features as well as increased frequency of occurrence of such events (Goswami et al., 2010). It is found that the extreme rainfall events in the NE region largely occur in association with the peak monsoon season (June - September) rather than isolated pre-monsoon thunderstorms. According to 
Projection for 2030 (Info Crop Model)
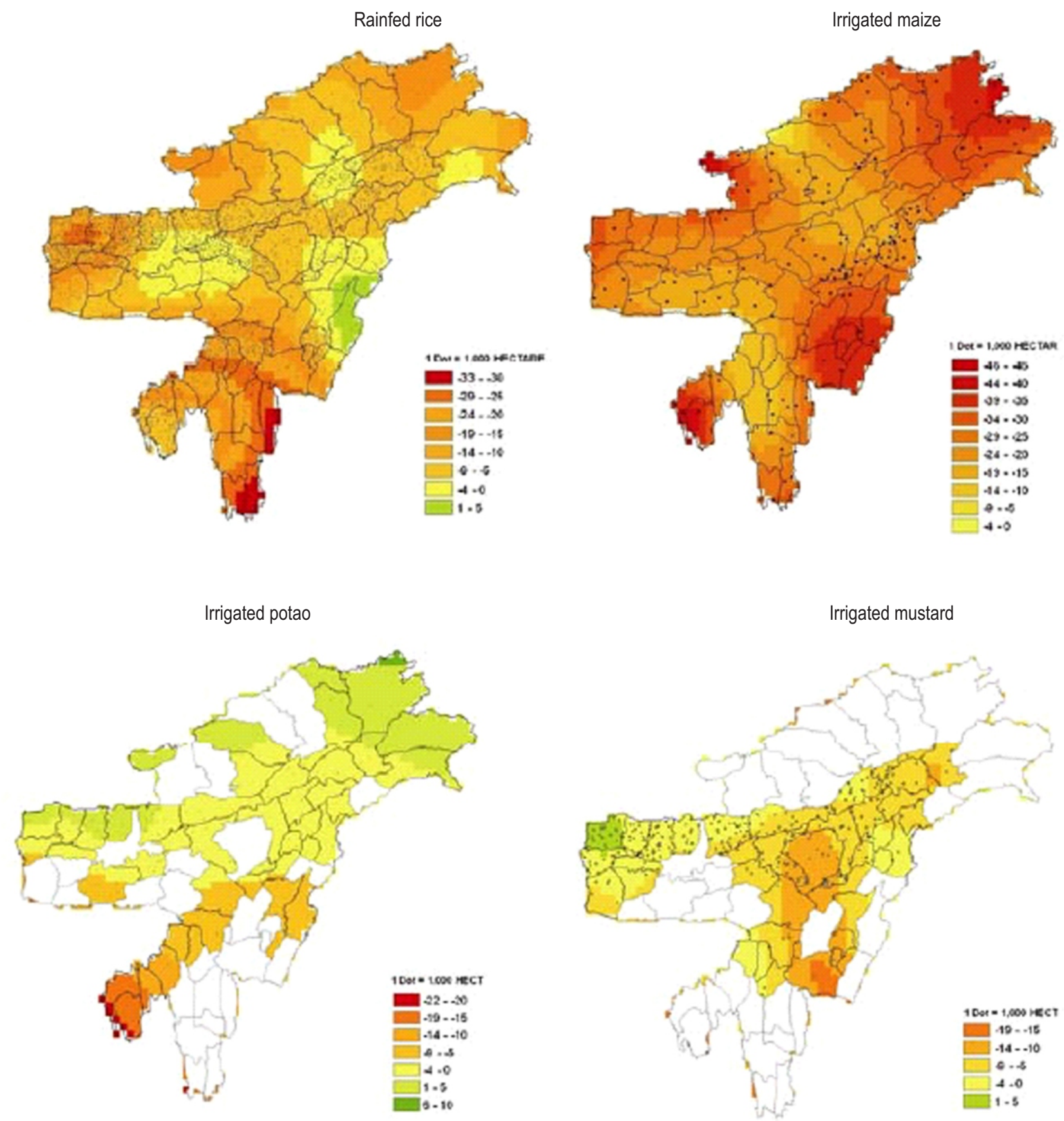

Fig. 3: Impact of climate change on different crops over North-Eastern region (Source: Kumar et al., 2011).

Goswami et al. (2010), the aggregate of extreme rain events over the region has a significant decreasing trend which was later confirmed by Mahanta et al. (2013). A similar finding was reported by Soraisam et al. (2018) who found that the total number of "low rainfall" months (arbitrarily defined as $<7 \mathrm{~mm} /$ day) increased substantially to of $34 \%-42 \%$. However, Varikoden and Ravadekar (2019) reported a significant decrease in "low rainfall" events and a significant increasing trend in very heavy ( $>95$ percentile) to extremely heavy ( $>99$ percentile) rainfall events during the period 2000-2015. Soraisam et al. (2018) used IMD gridded data 
Table 1: Trends of monthly rainfall (RF) at different places of North-east India

\begin{tabular}{lllllll}
\hline Year & Basar & Imphal & Jharnapani & Gangtok & Umiam & Kolasib \\
\hline Winter & $-1.3(-12.9)$ & $-0.6(-1.0)$ & $-0.1(0.0)$ & $-2.3^{* *}(-19.1)$ & $-1.7^{*}(-10.0)$ & $-1.9^{* *}(-10.3)$ \\
Pre-Monsoon & $1.4(36.8)$ & $1.5^{*}(15.2)$ & $-0.4(-24.0)$ & $-0.4(-13.9)$ & $1.4(39.8)$ & $0.6(31.5)$ \\
Monsoon & $-0.4(-26.5)$ & $0.1(0.7)$ & $-0.4(-38.1)$ & $0.9(65.7)$ & $-0.7(-32.5)$ & $2.5^{* *}(167.0)$ \\
Post-monsoon & $-0.5(-7.2)$ & $0.2(1.9)$ & $-2.1^{* *}(-80.4)$ & $-1.3(-27.7)$ & $-0.1(-0.1)$ & $0(1.5)$ \\
Annual & $-0.1(-8.3)$ & $1.3(23.5)$ & $-0.2(-62.9)$ & $-0.5(-36.2)$ & $-0.2(-12.1)$ & $1.6^{*}(173.5)$ \\
\hline
\end{tabular}

(Note: ${ }^{* * *},{ }^{* *}$ and ${ }^{*}$ denote trends at $1 \%, 5 \%$ and $10 \%$ significance level, respectively. Values indicate Mann Kendall's Z statistics and in the parentheses Sen's Slope represent the rate of change per decade (mm per decade) (source: Chakraborty et al., 2017b).

whereas Varikoden and Ravadekar (2019) used satellite data from Tropical Rainfall Measuring Mission (TRMM). The analysis on the frequency of extreme events during 1975-2005 by Soraisam et al. (2018) using IMD datasets revealed that there were four heaviest rainfall seasons with average rainfall of 23 $\mathrm{mm} /$ day in the NE region. Varikoden and Ravadekar (2019) identified thirty-two heavy rainfall events over the $\mathrm{NE}$ region based on the rainfall of the day exceeding $90^{\text {th }}$ percentile $(35-50$ $\mathrm{mm} /$ day) of seasonal rainfall. Prokop and Walanus (2015) advocated that the non-significant trend in annual rainfall in NE region is explained by the statistically significant increase in the frequency of extreme rain events and a significant decrease in low and moderate events during summer monsoon.

They studied daily rainfall data covering the century (1901-2000) from three IMD stations, Cherrapunji, Shillong and Guwahati in NE region. Not withstanding the biases in the findings of extreme events, a common idea flowing through all the narratives regarding extreme events was that NE region is vulnerable to rainfall related extreme events showing a significant change in its frequency and structure. Mahanta et al. (2013) studied heavy rainfall occurrences in North-east India and concluded that the most favourable time for occurrence of these events were between 10 June and 5 August. July records the largest number of HRF events followed by June and August. Ray et al. (2012) examined the daily rainfall data (28 years) of Barapani, Meghalaya and observed that the minimum number of droughts occurred 5 times in $39^{\text {th }}$ week, while the maximum number was observed 11 times in $28^{\text {th }}$ week during 1983-2010. The lowest annual rainfall of $13.46 \mathrm{~mm}$ occurred in the month of December and it occurred 13 times in 28 years in February.

The contradiction in the findings may be due to span of the study period, the difference in data sources and the method of identifying the categories of rainfall. The extreme monthly means of maximum and minimum temperature in NE region were projected to increase in the future period 2011-2060 (Soraisam et al., 2010). The study also revealed that during the same period, there were 39 highest maximum temperature months with average temperature of $34^{\circ} \mathrm{C} /$ day during summer months (Jun Sep) and 30 months of highest monthly maximum temperature of $30^{\circ} \mathrm{C} /$ day during winter. The extreme values of different weather parameters also increased over the region (Chakraborty et al.,
2014). The extremes of maximum temperature (Tmax) along with the relative humidity (RHeve) is changing leading to change in bio-climatic indicators like heat-Index or temperature humidity index (THI) as shown in Table 2. Further it is also seen that the normal days are decreasing sharply and the caution and extreme caution types of heat index days are increasing leading to change in the bio-climate altogether (Fig. 2).

Vulnerability to climate change: Generic definition of vulnerability is "the likelihood of injury, death, loss, disruption of livelihood or other harm in an extreme event, and/or unusual difficulties in recovering from such effects" (Wisner, 2002). In the context of climate change IPCC defined vulnerability as "the degree to which a system is susceptible to or unable to cope with adverse effects of climate change, including climate variability and extremes'. There are two streams of assessment of vulnerability, the contextual vulnerability assessment and the outcome vulnerability assessment (IPCC). Rabindranath et al. (2011) used the outcome vulnerability assessment and developed vulnerability indices to understand the vulnerability of three key sectors of NE region. Understandably, NE region is highly vulnerable to climate change due to its geo-ecological fragility, strategic location, trans-boundary river basin and

Table 2: Trends in the extreme values of weather parameters along with the bio-climatic variables

\begin{tabular}{lllll}
\hline & Tmax & RHeve & HI & THI \\
\hline Jan & $0.5^{* * *}$ & $-0.6^{* * *}$ & $0.5^{* * *}$ & $0.2^{* * *}$ \\
Feb & $0.6^{* * *}$ & $-0.4^{* * *}$ & $0.5^{* * *}$ & $0.3^{* * *}$ \\
Mar & $0.4^{* * *}$ & $-0.4^{* * *}$ & 0.2 & 0.1 \\
Apr & $0.3^{* *}$ & $-0.4^{* * *}$ & 0.1 & 0.1 \\
May & $0.5^{* * *}$ & -0.2 & $0.2^{* *}$ & $0.2^{* *}$ \\
Jun & $0.5^{* * *}$ & -0.1 & 0.1 & 0.1 \\
Jul & $0.5^{* * *}$ & $-0.3^{* * *}$ & 0.1 & 0.1 \\
Aug & $0.4^{* * *}$ & $-0.5^{* * *}$ & -0.1 & 0.1 \\
Sep & $0.4^{* * *}$ & $-0.5^{* * *}$ & -0.1 & -0.1 \\
Oct & $0.4^{* * *}$ & $-0.4^{* * *}$ & 0.1 & 0.1 \\
Nov & $0.5^{* * *}$ & $-0.5^{* * *}$ & $0.4^{* * *}$ & -0.1 \\
Dec & $0.4^{* * *}$ & $-0.5^{* * *}$ & $0.5^{* * *}$ & 0.1 \\
\hline
\end{tabular}

***, ${ }^{* *}$ and * denote trends at $1 \%, 5 \%$ and $10 \%$ significance level, respectively (Source: Chakraborty et al., 2014). 
inherent socio-economic instability (Das, 2009). Ravindranath et al. (2011), observed that in NE region, higher agricultural vulnerability was observed in the northern parts and declined towards the south. District level assessment revealed that Tirap, West Siang, Nalbari, Changlang and Dibrugarh were the most vulnerable districts to current climate variability. On the other hand, state level assessment revealed that Manipur was agriculturally the most vulnerable state whereas Tripura was the least vulnerable (Yomcha, 2019). The region has a powerful hydrological and monsoon regime, with the Brahmaputra and the Barak river systems, which pose both as a resource and a source of vulnerability (Das, 2009). Majority of the districts in NE region is ranked as very highly vulnerable with respect to floods are also ranked very highly vulnerable with respect to drought (Ravindranath et al., 2011). The forests in NE region are moderately vulnerable to climate change.

Future projections: In the recent past, the analysis on future climate change over the NE region has been done by the Ministry of Environment and Forests, Government of India (INCCA, 2010) using PRECIS, a regional climate model. The projections showed a rise in annual average rainfall and temperature by $0.3 \%$ to $3 \%$ and by $1.8^{\circ} \mathrm{C}$ to $2.1^{\circ} \mathrm{C}$ by 2030 . The work of Dash et al. (2012) on RegCM3, another climate model, projects an increase in the annual mean surface temperature and rainfall by about $0.64^{\circ} \mathrm{C}$ and $0.09 \mathrm{~mm} /$ day during $2011-2040$ and by $5.15^{\circ} \mathrm{C}$ and 0.48 $\mathrm{mm} /$ day during 2071-2100. Soraisam et al. (2018) used the Coordinated Regional Downscaling Experiment (CORDEX) South Asia output for future climate projections under RCP4.5 conditions, which represents scenario of moderate anthropogenic emissions from 2011 to 2060.

The study projected a significant increasing trend in the minimum temperature (in the range of $0.71^{\circ} \mathrm{C}-2.6^{\circ} \mathrm{C}$ per 50 years for summer and $1.15^{\circ} \mathrm{C}-2.61^{\circ} \mathrm{C}$ per 50 years for winter season) and maximum temperature $\left(0.33^{\circ} \mathrm{C}-2.86^{\circ} \mathrm{C}\right.$ per 50 years for summer and $0.87^{\circ} \mathrm{C}-3.01^{\circ} \mathrm{C}$ per 50 years for winter season), and a insignificant decreasing trend in summer and winter rainfall in the NE region for 2011-2060 period. Kumar and Dimri (2018) also used the CORDEX output to project the longterm change in temperature and precipitation for different RCP scenarios, ranging from the least emission RCP2.6 to strongest emission RCP8.5. The rate of long-term increase in temperature ranged between 0.01 and $0.07^{\circ} \mathrm{C} /$ year across the region in RCP2.6 to RCP8.5 scenarios. A change in daily mean precipitation ranging from $-60 \%$ (during winter) to $+40 \%$ during post-monsoon was projected across different RCPs in the NE region (Kumar and Dimri, 2018).

Impact of climate change: Climate change has affected the earth's ecosystems and communities around the world. The impact of climate change in NE region is manifested in the form of flood and other rain related extreme events which has reportedly caused widespread destruction in the region. According to IPCC report (2007a), several districts of Assam were badly affected due to drought like situations consecutively for two years in 2005 and
2006 which had a signature of climate change on them. The state suffered great loss to the tune of more than rupees 100 crores due to crop failure and it affected over 26 million people whose livelihood were based on agriculture. During the same period, other states of the NE region also received rainfall of $30-40 \%$ below normal, except Mizoram (Das, 2009). Rabindranath et al. (2011) approximated the impact of climate change on agriculture by model simulations using INFOCROP14, for rice under near future scenario (2021-2050). The result showed that among 64 districts of NE region, the yield will undergo change in most districts in the future under $\mathrm{A} 1 \mathrm{~B}$ scenario, with increase in yield projected for 21 districts and a decrease in yield for 43 districts (up to $10 \%$ ). Kumar et al. (2011) using future scenario for 2030 , predicted that due to climate change the rainfed rice yield may decrease up to $35 \%$ with most of the area losing $10 \%$ yield (Fig. 3). Irrigated maize yields are projected to reduce by about $40 \%$. In case of rabi season crops, wheat yield is projected to reduce up to $20 \%$. Potato yield is likely to increase marginally up to $5 \%$ in the upper parts of NE region due to climate change, but in the central parts projected yield loss is about $4 \%$, and in southern parts of the region the negative impacts will be much higher. Irrigated is also projected to lose yield up to $10 \%$ in most areas mustard crop (Kumar etal. 2011).

Impact of climate change on tea was modelled using the Cranfield University Plantation Productivity Analysis for Tea (CUPPA Tea) Model which simulates the growth and yield of tea using the WorldClim and IPCC4 climate data by Dutta (2014). The study observed a change in the production period of tea which may have been caused by sudden spurts in rainfall and temperature. Tea yield was found to be negatively impacted at monthly average temperature greater than $26.6^{\circ} \mathrm{C}$ and at high precipitation intensity while it might be insensitive to drought frequency (Duncan et al., 2016). The impacts of climate change on plant physiology and the nature of its pests' activities have brought newer pests in the tea ecosystem in the NE region (Roy, 2019). Impact of climate change on other sectors such as water resources and forest has been estimated by Rabindranath et al. (2011). Hydrological model SWAT was used to simulate the impact of climate change on water resources which showed both spatial and temporal variability.

Both drought and floods are expected to increase in the region. Impact on forest was modelled using IBIS 18 which projected a high vulnerability for the Himalayan biodiversity hotspot. However, the net primary productivity of forests in the NE region is projected to increase by $23 \%$ followed by increase in biomass and soil carbon. Singh et al. (2010) conducted a study in Meghalaya and reported that the average productivity of rice in normal year was $3157 \mathrm{~kg} \mathrm{ha}^{-1}$ but in the drought year there was $53 \%$ loss in yield. In Meghalaya, the farmers usually select traditional rice varieties like Ranjit, Mahsuri and Aijong and decrease in area under rice in case of drought was reported. Singh et al. (2013) in their study during 2011-12 in 10 villages of West and South Garo Hills of Meghalaya reported that during drought years, income from non-farm activities provided the largest share of household income; followed by income from sale 
of crops other than rice and wages from off-farm activities. When crops failed during drought year, incomes from different sources were adversely affected. Income from fisheries were worst affected, followed by income from sale of rice, vegetables, animals and other crops. During normal year, rice was available for five months but only for three months during drought year. In this changing climatic scenario, the altered dynamics of monsoon along with temperature and humidity has created many changes in the environment which may not pose serious threat to the existence of human beings per se but may make the environment suitable for many microbes and the vectors which were earlier not present in the area. Khan et al. (2013) detected 18 species of mosquitoes in the state of Meghalaya which were never reported before. Increase in Dengue and Chikungunya due to the prevalence of Aedes aegypti and Ae. Albopictus mosquitoes were reported by Dutta et al. (2011). Prakash et al. (2006) depicts the increase in major vectors of malaria Anopheles baimai (previously An. dirus) and An. minimus in Meghalaya. Japanese Encephalitis vectors like Culexvishnui, Cx. gelidus etc. finds congenial breeding places in paddy growing Jhum area of Meghalaya in this climatic situation and their population is growing (Khan et al., 2013).

All these studies indicate that the vectors of different diseases of human and cattle both are finding congenial environment which has probably been possible due to the changes in the weather of the region. Climate change is often exemplified by increased temperature. It was clear from the studies that globally as well as regionally the temperature has increased. However, variability in temperature is one of the primary factors affecting agriculture, forestry, water supplies, human and ecosystem health. The rate of increase in average temperature over the region was higher greater than the global average. It was observed that in spite of huge variation in magnitude and direction of precipitation trend among various meteorological subdivisions, overall, no clear-cut trend was observed on both spatial and temporal scale.

Due to climate change is being, high rainfall areas are facing drought like situations in recent years and on the contrary occurrence of flood was witnessed even in low rainfall areas. Along with the diverse geography of different states, annual precipitation records exhibited significant inter-annual variability, which makes trend analysis for water resource planning, management, and policy making very difficult. Since the region is experiencing rise in temperature, it is recommended that the state-wise climate change action plan showed be adequately and inclusively framed and implemented to save this region from ill effects of climate change. Further, more elaborate and deeper studies are required to investigate various causes of climate change to enable adaptable and mitigatable strategies distinctively.

\section{Acknowledgments}

The authors are grateful to the Department of Biotechnology (DBT), Government. of India, New Delhi for financial assistance under the scheme of DBT Overseas fellowship for special programme for North-East 2017-18 from which this paper has been prepared. Authors are also thankful to the Director, ICAR Research Complex for NEH Region to facilitate and implement this research.

\section{Add-on Information}

Authors' contribution: A. Roy, D. Chakraborty, N.U. Singh: Writing and editing the manuscript; D. Kolady: Conceptualization the idea and editing; B. Paudel: Secondary data gathering and writing; A. Yumnam: Fact, figure correction and writing; $\mathbf{N}$. Mridha: Writing the draft manuscript.

Research content: The research content of manuscript is original and has not been published elsewhere.

\section{Ethical approval: NotApplicable.}

Conflict of interest: The authors declare that there is no conflict of interest.

Data from other sources: NotApplicable.

Consent to publish: All authors agree to publish the paper in Journal of Environmental Biology.

\section{References}

Barman, M. and P. Goswami: Impact of climate change on characteristics of rainfall and temperature in Kamrup district of Assam. Int. Adva. Res. J. Sci. Enginee. Technol., 6, 70-74 (2019).

Chakraborty, D., S. Saha, R.K. Singh, B.K. Sethy, A. Kumar, U.S. Saikia, S.K. Das, B. Makdoh, Tasvina R. Borah, A. Nomita Chanu, I. Walling, P.S. Rolling Anal, S. Chowdhury and D. Daschaudhuri: Trend analysis and change point detection of mean air temperature: A spatio-temporal perspective of North-Eastern India. Environ. Proc., 4, 937-957 (2017a).

Chakraborty, D., R.K. Singh, S. Saha, A. Roy, B.K. Sethy, A. Kumar and S.V. Ngachan: Increase in extreme day temperature in hills of Meghalaya: Its possible ecological and bio-meteorological effect. J. Agrometeorol., 16 (Special Issue-I), 147-152 (2014).

Chakraborty, D.,S. Saha, R.K. Singh, B.K. Sethy, A. Kumar, U.S. Saikia, S.K. Das, B. Makdoh, Tasvina R. Borah, A. Nomita Chanu, I. Walling, P.S. Rolling Anal, S. Chowdhury and D. Daschaudhuri: Spatio-temporal trends and change point detection in rainfall in different parts of north-eastern Indian states. J. Agrometeorol., 19, 160-163 (2017).

Chakraborty, D., V.K. Sehgal, R. Dhakar, E. Varghese, D.K. Das and M. Ray: Changes in daily maximum temperature extremes across India over 1951-2014 and their relation with cereal crop productivity. Stochastic Environ. Res. RiskAssess., 32, 3067-3081 (2018).

Chakraborty, D., V.K. Sehgal, R. Dhakar, M. Ray and D.K. Das: Spatiotemporal trend in heat waves over India and its impact assessment on wheat crop. Theor. Appl. Climatol., 138, 1925-1937 (2019).

Choudhury, B.U., Anup Das, S.V. Ngachan, A. Slong, L.J. Bordoloi and P. Chowdhury: Trend analysis of longterm weather variables in mid altitude Meghalaya, North-East India. J. Agricul. Phys., 12, 12-22 (2012).

Cohn, T.A. and H.F. Lins: Nature's style: Naturally trendy. Geophy. Res. 
Lett., 32, 1-5(2005).

Cox, P.M., Richard A. Betts, Chris D. Jones, Steven A. Spall and lan J. Totterdell: Acceleration of global warming due to carbon-cycle feedbacks in a coupled climate model. Nature, 408, 184-187 (2000).

Das, P.J.: Water and climate induced vulnerability in northeast India: Concerns for environmental security and sustainability. WATCH Res. Rep., 1, 1-9 (2009).

Dash, S.K. and A. Mamgain: Changes in the frequency of different categories of temperature extremes in India. J. Appl. Meteorol. Climatol., 50, 1842-1858 (2011).

Dash, S.K., A. Anil Nair, Makarand A. Kulkarni and U.C. Mohanty: Characteristic changes in the long and short spells of different rain intensities in India. Theor. Appl. Climatol., 105, 563-570 (2011).

Dash, S.K., M.S. Shekhar and G.P. Singh: Simulation of Indian summer monsoon circulation and rainfall using Reg CM3. Theor. Appl. Climatol., 86, 161-172(2006).

Dash, S.K., M.A. Kulkarni, U.C. Mohanty and K. Prasad: Changes in the characteristics of rain events in India. J. Geophy. Res., 114, 1-12 (2009).

Dash, S.K., N. Sharma, K.C. Pattnayak, X.J. Gao and Y. Shi: Temperature and precipitation changes in the north-east India and their future projections. Global Plane. Chan., 98-99, 31-44 (2012).

Deka, R.L.,C. Mahanta and K.K. Nath: Trends and fluctuations of temperature regime of north east India. ISPRS Archives XXXVIII8/W3 Workshop Proceedings: Impact of Climate Change on Agriculture, pp. 376-380 (2009).

Duncana, J.M.A., S.D. Saikiab, N. Guptab and E.M. Biggs: Observing climate impacts on tea yield in Assam, India. Appl. Geogra., 77, 64-71 (2016).

Dutta, P., S. A. Khan, A.M. Khan, J. Borah, P. Choudhury and J. Mahanta: First evidence of Chikungunya virus infection in Assam: North-east India. T. Roy. Soc. Trop. Med. H., 105, 355-357 (2011).

Dutta, R.: Climate change and its impact on tea in North-east India. J. Water Clim. Chan., 5, 625-632 (2014).

Goswami, B.B., P. Mukhopadhyay, R. Mahanta and B.N. Goswami: Multiscale interaction with topography and extreme rainfall events in the northeast Indian region. J. Geophy. Res., 115, 1-12 (2010).

Herzog, A.V., Timothy E. Lipman, Jennifer L. Edwards and D.M. Kammen: Renewable energy: A viable choice. Environment, 43,118 (2001).

INCCA: Climate Change and India: a $4 \times 4$ Assessment. -ASectorial and Regional Analysis for 2030s. Ministry of Environment and Forests, Government of India (2010).

IPCC: Climate Change 2001: Synthesis Report. A Contribution of Working Groups I, II, and III to the Third Assessment Report of the Integovernmental Panel on Climate Change (Eds.: Watson, R.T. and the Core Writing Team). Cambridge University Press, Cambridge, United Kingdom, and New York, NY, USA (2001).

IPCC: Summary for Policymakers. In: Climate Change: The Physical Science Basis. Contribution of Working Group I to the Fourth Assessment Report of the Intergovernmental Panel on Climate Change (Eds.: S. Solomon, D. Qin, M. Manning, Z. Chen, M. Marquis, K.B. Averyt, M. Tignor and H.L. Miller). Cambridge University Press, Cambridge, United Kingdom and New York, NY, USA (2007a).

IPCC: Summary for Policymakers. In: Climate Change 2007: Mitigation. Contribution of Working Group III to the Fourth Assessment Report of the Intergovernmental Panel on Climate Change [(eds.: B. Metz, O.R. Davidson, P.R. Bosch, R. Dave and L.A. Meyer)], Cambridge University Press, Cambridge, United Kingdom and New York, NY, USA(2007b).
Jain, S.K., V. Kumar and M. Saharia: Analysisof rainfall and temperature trends in North-East India. Int. J. Climatol., 33, 968-978 (2013).

Jhajharia, D. and V.P. Singh: Trends in temperature, diurnal temperature range and sunshine duration in North-east India. Int. J. Climatol., 31, 1353-1367(2011).

Jhajharia, D., S.K. Shrivastava, D. Sarkar and S. Sarkar: Temporal characteristics of pan evaporation trends under the humid conditions of northeast India. Agric. For. Meteorol., 149, 763-770 (2009).

Katz, R.W. and B.G. Brown Extreme events in a changing climate: Variability is more important than averages. Clim. Chan., 21, 289-302 (1992).

Khan, S.A., P. Dutta, J. Borah and J. Mahanta: Survey of new mosquito species of Meghalaya, India. J. Environ. Biol., 34, 191-195(2013).

Kumar, D. and A.P. Dimri: Regional climate projections for North-east India: An appraisal from CORDEX South Asia experiment. Theor. Appl. Climatol., 134, 1065-1081 (2018).

Kumar, S.N., P.K. Aggarwal, S. Rani, S. Jain, R. Saxena and N. Chauhan: Impact of climate change on crop productivity in Western Ghats, coastal and north-eastern regions of India. Curr. Sci., 101, 332-341 (2011).

NOAA: State of the Climate: Global Climate Report for Annual 2019, National Centers for Environmental Information (2020).

Pant, G.B. and K.R. Kumar: Climates of South Asia. John Wiley and Sons, New York, 280 pages (1997).

Parry, M.L. and T.R. Carter: The effect of climatic variations on agricultural risk. Clima. Chan., 7, 95-110 (1985).

Prakash, A., C. Walton, D.R. Bhattacharyya, S.O. Loughlin, P.K. Mohapatra and J. Mahanta: Molecular characterization and species identification of the Anopheles dirus and An. minimus complexes in north-east India using r-DNA ITS-2. Acta. Tropica, 100, 156-161 (2006).

Prokop, P. and A. Walanus: Variation in the orographic extreme rain events over the Meghalaya hills in north-east India in the two halves of the twentieth century. Theor. Appl. Climatol., 121, 389-399 (2015).

Ravindranath, N.H., S. Rao, N. Sharma, M. Nair, R. Gopalakrishnan, A.S. Rao, S. Malaviya, R. Tiwari, A. Sagadevan, M. Munsi, N. Krishna and G. Bala: Climate change vulnerability profiles for North-east India. Curr. Sci., 101, 384-394(2011).

Roy, S., A.K. Barooah, K.Z. Ahmed, R.D. Baruah, A.K. Prasad and A. Mukhopadhyay: Impact of climate change on tea pest status in northeast India and effective plans for mitigation. Acta. Ecolog. Sini., 40, 432-442 (2019).

Saha, S., D. Chakraborty, B.U. Choudhury, S.B. Singh, N. Chinza, C. Lalzarliana, S.K. Dutta, S. Chowdhury, T. Boopathi, A.R. Lungmuana and S.V. Ngachan: Spatial variability in temporal trends of precipitation and its impact on the agricultural scenario of Mizoram. Curr. Sci., 109, 2278-2282 (2015).

Saha, S., D. Chakraborty, R.K. Paul, S. Samanta and S.B. Singh: Disparity in rainfall trend and patterns among different regions: Analysis of 158 years' time series of rainfall dataset across India. Theore. Appl. Climatol., 134, 381-395 (2018).

Scholz, F. and U. Hasse: Permanent wood sequestration: The solution to the global carbon dioxide problem. Chemsuschem., 1, 381-384 (2008).

Shahin, M., H.J.L. Van Oorschot and S.J. De Lange: Statistical Analysis in Water Resources Engineering. AA Balkema, Rotterdam, 394 pages (1993).

Soraisam, B., A. Karumuri and D.S. Pai: Uncertainties in observations and climate projections for the North-east India. Global Plane. 
Chan., 160, 96-108 (2018).

Varikoden, $\mathrm{H}$. and J.V. Ravadekar: On the extreme rainfall events during the southwest monsoon season in northeast regions of the Indian subcontinent. Meteorol. Applic., 1822, 1-13 (2019).

Wisner, B.: Who? What? Where? When? In an Emergency: Notes on possible indicators of vulnerability and resilience by phase of the disaster management cycle and social actor. In: Environment and Human Security: Contributions to a Workshop in Bonn, Germany. pp. 12 (2002).

Yomcha, M., F.M. Sheikh, D. Rymbai and R. Singh: State level agricultural vulnerability to climate change in North-eastern region of India. Indian J. Hill Farm., 32, 96-103 (2019). 